\title{
Nursing and primary health care in Brazil: a mini review
}

\begin{abstract}
This study aimed to analyze the scientific production on Nursing in PHC in Brazil, from the MEDLINE, LILACS, SCIELO, BDENF - Enfermagem (Brazil) and PAHO databases. The analysis showed that the Nursing work process in Primary Health Care requires programmatic and universal care, as a strategy to strengthen the Unified Health System (SUS) and improve the quality of life of the population. However, the nursing workforce is subject to an intense workload, which is inferred in the healthillness-work-care process.
\end{abstract}

Keywords: nursing, primary health care, job
Volume 5 Issue 3 - 2018

\author{
Francisco Rosemiro Guimarães Ximenes \\ Neto
}

State University of Vale do Acaraú (UVA), Brazil

Correspondence: Francisco Rosemiro Guimarães Ximenes Neto, State University of Acaraú Valley (UVA), Brazil,Tel+55 88 98|40 |688, Email: rosemironeto@gmail.com

Received: April 02, 2018 | Published: June 06, 2018

\section{Introduction}

The institutionalization of the Unified Health System (SUS), by the Brazilian Federal Constitution of 1988, triggered an intense process of decentralization of policies, programs, projects, actions and health services, among them Primary Health Care (PHC). ${ }^{1}$ In 1994, the Brazilian Ministry of Health implemented the Family Health Program (FHP), as part of the scope of PHC universalization in the country. The FHP in its organicity required a minimum team composed of Nurse, General Practitioner, Nursing Assistant and Community Health Agents, based in a Health Center, with an attached health territory. With the qualitative advances of the indicators, the FHP in 1997 becomes policy, the Family Health Strategy (FHS). ${ }^{1-3}$ Since then, Nursing in PHA has experienced growth in its workforce, as well as the expansion and internalization of the labor market, public employment and community care practices for families. ${ }^{4}$ Thus, the study aims to analyze the scientific production on Nursing in PHA in Brazil.

\section{Method}

Study of narrative review of the literature, conducted during the period from January to April, 2018, from the databases MEDLINE, LILACS, SCIELO, BDENF - Nursing (Brazil) and PAHO. Narrative reviews "are broad, appropriate publications to describe and discuss the development or 'state of the art' of a given subject from a theoretical or contextual point of view". ${ }^{5}$ For the composition of the study, the following inclusion criteria were defined: original articles, published in full in the Portuguese language, between 2009 and 2017. The terms of the consultations to the titles used were: "Nursing", "Primary Health Care", "Attention Basic to Health "and" Work ". The booleans used were: "AND" and "OR".

\section{Results and discussion}

Since the 1920s, Brazilian Nursing has been developing an important social and health role in the field of Public Health, especially in PHC, during the health-disease-care process for families, subjects and communities. The nurses' work process, in PHC, is socially determined and influenced by the health policies instituted by the political scenario and the territorialized historical culture. ${ }^{3}$ Figure 1 presents the results of the research, for composition of the narrative review, after analysis of the databases. From the total of 10 identified studies, three were selected, two of them involving the auxiliary and technical staff of Nursing and one the Nursing Team, which in Brazil, with the promulgation of the Law of Professional Exercise No. $7,498 / 1986$, organized into three categories of professionals, with a workforce of 2,025,000 workers, and its composition and work force were stratified: Nursing - 484,530, Nursing Technician - 1,117,409, and Nursing Assistant - 422,773. ${ }^{6}$

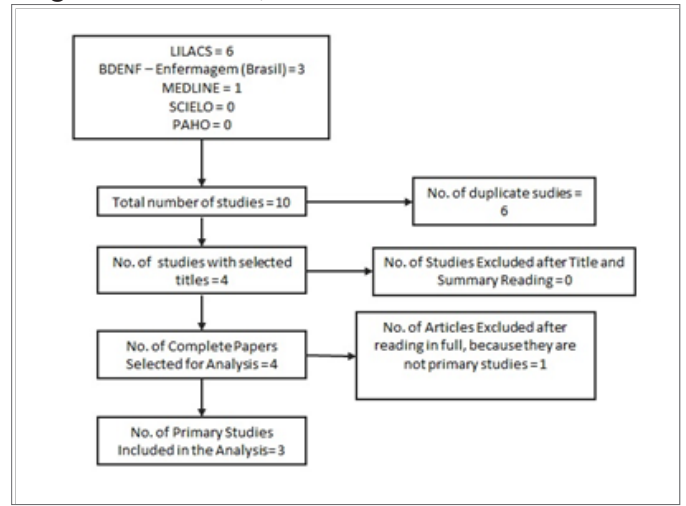

Figure I Flowchart of the review process for search, identification, selection, and inclusion of studies.

The study by Scherer et al., ${ }^{7}$ is a multicenter study carried out in three Brazilian administrative regions, with the purpose of analyzing the "main aspects that contribute to increase the workloads of nursing technicians" who work in PHC. The study shows low monthly remuneration, lack of material resources, work overload, wear and tear, relationship with the user and the shortage of workers, which contributes to the prevalence of psychic and physiological loads and, with the consequent sickness of the workers.

The study by David et al., ${ }^{8}$ evaluates the impact of work organization on the health of the Nursing Team based on a crosssectional study, showing that the disorganization in the development of the work process associated to the relationships among co-workers, with the clientele, have affected quality of life at work and influenced the health-illness-work-care process of Nursing workers in PHC, with increased levels of stress and suffering at work, as well as social life. 
The studies of Scherer \& David, et al., ${ }^{7,8}$ identified what Dejours points out, ${ }^{9}$ that the work environment can be a space of experiences of pleasure and/or suffering. And that depending on your organization and the conditions to which the workers are subjected, can affect your mental health. Such suffering "can be attributed to the clash between an individual story, bearer of projects, hopes and desires, and an organization of work that ignores them." Cardoso et al., ${ }^{10}$ investigated the work process of Nursing Assistants and Nursing Technician in a municipality in the State of São Paulo, evidencing two distinct modes of work process, which are: the predominance of practices aimed at the care of subjects in need of face diseases/health problems, and the development of the work process, with a view to integral attention.

The work process of caring in nursing "has as its object the care demanded by individuals, families, social groups, communities and collectivities". ${ }^{11}$ In the case of the HFS, as a structuring policy of PHC in SUS, it has demanded a workforce that provides a complex, diversified work process with daily and routine emergent demands, involving actions of prediction, prediction, prevention of risks, injuries and diseases; education, promotion and protection of health; treatment, recovery and rehabilitation, seeking to respond to the demands of care, social and sanitary,$^{3}$ and Nursing as an important protagonist of Brazilian Public Health, should move to a level of intersectoral and multicultural care, which is based not only in the health referential as a quality of life, but also to an extended care perspective, which seeks a coalition for holistic-integral attention, based on the Family-Team conformation of the HFS-Communitylocal socio-community and local networks.

\section{Conclusion}

The study shows that the Nursing work process in the PHC in Brazil demands specific client care, in a programmatic way, as well as with practices that have contributed to the fulfillment of the integrality of care and, consequently, the strengthening of SUS and quality improvement of population life. However, nursing professionals are subject to an intense workload that has directly influenced their health-illness-work-care process, which has corroborated with the illness of these workers.

\section{Acknowledgments}

None.

\section{Conflict of interests}

Author declares that there is no conflict of interest.

\section{Refrences}

1. Ximenes Neto FRG, Ferreira GB, Ximenes MRG, et al. Necessidades de qualificação, dificuldades e facilidades dos Técnicos de Enfermagem na Estratégia Saúde da Família. Sanare. 2016;15(1):47-54.

2. Mendes EV. O cuidado das condições crônicas na atenção primária à saúde: o imperativo da consolidação da estratégia da saúde da família. Organização Pan-Americana da Saúde. 2012.

3. Ximenes Neto FRG. Work of Nurses in Primary Health Care in Brazil: historical analysis and professional challenges. São Paulo: Universidade Federal de São Paulo (UNIFESP)/Escola Paulista de Enfermagem/ Programa de Pós-graduação em Enfermagem, 2013.

4. Ximenes Neto FRG, Sampaio JJC. Atenção Primária à Saúde e território: histórico, concepções e políticas. In: Machado MH, Soares Neto JJ, editors. O PMM e a Atenção Básica. Curitiba: Editora Prismas; 2017:225 .

5. Rother ET. Revisão sistemática X revisão narrativa. Acta paul enferm. 2007;20(2):5-6.

6. Brasil. Conselho Federal de Enfermagem (COFEN). Enfermagem em números.

7. Scherer MDA, Oliveira NA, Pires DEP, et al. Aumento das cargas de trabalho em técnicos de Enfermagem na Atenção Primária à Saúde no Brasil. Trabalho, Educação e Saúde. 2016;14(Suppl. 1):89-104.

8. David HMSL, Mauro MYC, Silva VG, et al. Organização do trabalho de enfermagem na Atenção Básica: uma questão para a saúde do trabalhador. Texto \& Contexto-Enfermagem. 2009;18(2):206-214.

9. Dejours C. A loucura do trabalho: estudo de psicopatologia do trabalho. 6th ed. São Paulo: Cortez/Oboré; 2015.

10. Cardoso TZ, Pereira MJB, Campos LVO, et al. Processo de trabalho de auxiliares e técnicos de enfermagem na atenção básica à saúde. Rev bras enferm. 2011;64(6):1087-1093.

11. Sanna MC. Os processos de trabalho em Enfermagem. Rev bras enferm. 2007;60(2):221-224. 